\title{
Short-term and medium-term outcomes of transapical aortic valve implantation as a single-strategy approach: one center's experience
}

\author{
Júlia Čanádyováa ${ }^{1}$, Aleš Mokráček ${ }^{1}$, Ladislav Pešl ${ }^{2}$, Vojtěch Kurfirst ${ }^{1}$, Mirek Šulda ${ }^{1}$ \\ ${ }^{1}$ Department of Cardiac Surgery, Hospital České Budějovice, Czech Republic \\ ${ }^{2}$ Department of Cardiology, Hospital České Budějovice, Czech Republic
}

Kardiochirurgia i Torakochirurgia Polska 2015; 12 (2): 95-102

\begin{abstract}
Introduction: Transcatheter aortic valve replacement has been developed as an alternative option for surgical high-risk or inoperable patients with severe symptomatic aortic stenosis. Aim of the study was to evaluate the outcomes of patients undergoing transapical aortic valve replacement as a singlestrategy option by a single-center multidisciplinary heart team. Material and methods: Between June 2009 and December 2014, 41 patients underwent transapical transcatheter aortic valve implantation (TA-TAVI) at our institution. All patients received Edwards SAPIEN balloon expandable pericardial valves (Edwards Lifesciences, Irvine, CA, USA). Our center followed a "clear transapical strategy" for all patients.

Results: The mean age of the patients was 79.6 years, and the mean logistic EuroSCORE was $21.06 \pm 12.82 \%$. Fifteen patients (36.6\%) underwent redo operations. Complications included stroke $(n=1)$, re-exploration for bleeding or cardiac tamponade $(n=4)$, renal failure requiring temporary hemodialysis $(n=4)$ and permanent pacemaker implantation $(n=3)$. There were no myocardial infarctions or coronary obstruction. The total 30 -day mortality rate was $17.1 \%$ (7 patients). Postoperative intensive care unit stay was $4.6 \pm 5.7$ days, and mean hospitalization was $11.6 \pm 7.2$ days.

Conclusions: The TA-TAVI approach provides good results in terms of early and midterm outcomes. This approach is feasible and safe for patients who have high surgical risk.

Key words: aortic stenosis, transapical valve replacement.
\end{abstract}

\section{Streszczenie}

Wstęp: Technika przezcewnikowej wymiany zastawki aortalnej została opracowana jako alternatywa dla pacjentów o wysokim ryzyku operacyjnym lub nieoperacyjnych z ciężką objawową stenozą aortalną.

Celem niniejszej pracy była ocena wyników pacjentów poddawanych przezkoniuszkowej wymianie zastawki aortalnej jako jedynej opcji terapeutycznej przez wielodyscyplinarny zespół sercowy w pojedynczym ośrodku.

Materiał i metody: Pomiędzy czerwcem 2009 r. a grudniem 2014 r. 41 pacjentów poddano przezkoniuszkowej implantacji zastawki aortalnej (TA-TAVI) w ośrodku autorów. Wszyscy chorzy otrzymali balonowe zastawki osierdziowe Edwards SAPIEN (Edwards Lifesciences, Irvine, CA, USA). Ośrodek autorów stosowat „jasną strategię” przezkoniuszkową u wszystkich pacjentów. Wyniki: Średni wiek pacjentów wyniósł 79,6 roku, średni wynik logistic EuroSCORE wynosit 21,06 $\pm 12,82 \%$. Piętnastu pacjentów $(36,6 \%)$ przeszło powtórne operacje. Wystąpiły następujące komplikacje: udar mózgu $(n=1)$, reeksploracja ze względu na krwawienie lub tamponadę serca $(n=4)$, niewydolność nerek wymagająca czasowej hemodializy $(n=4)$ oraz stałe wszczepienie stymulatora $(n=3)$. Nie odnotowano żadnego zawału mięśnia sercowego ani zatoru wieńcowego. Śmiertelność 30-dniowa wyniosła 17,1\% (7 pacjentów). Czas pooperacyjnego pobytu na oddziale intensywnej terapii wyniósł 4,6 \pm 5,7 dnia, a średni czas hospitalizacji: 11,6 \pm 7,2 dnia.

Wnioski: Zastosowanie TA-TAVI zapewnia dobre rezultaty w zakresie wczesnych i średnioodległych wyników. Strategia ta jest możliwa do wykonania i bezpieczna u pacjentów o wysokim ryzyku operacyjnym.

Słowa kluczowe: zwężenie zastawki aortalnej, przezkoniuszkowa wymiana zastawki.

tients with severe symptomatic aortic valve stenosis [1]. With aging of the population, the number of older and sicker patients has increased, and a significant portion of

Address for correspondence: Júlia Čanádyová, MD, Department of Cardiac Surgery, Hospital České Budějovice, Boženy Němcové 54, 37001 České Budějovice, Czech Republic, phone: 00420387874202, e-mail: canadyova.julia@gmail.com 
them are not indicated for surgical intervention because of advanced age and its associated comorbidities [2]. Transcatheter aortic valve implantation (TAVI) represents an attractive approach to treat high-risk or inoperable patients, with promising results. Transcatheter aortic valve implantation can be performed through several access approaches: transfemoral, transaortic, trans-subclavian and transapical. In most centers performing TAVI, a transfemoral first approach policy is applied [3]. However, unsuitable peripheral arterial anatomy, bleeding and vascular complications frequently occur and are associated with increased risk of perioperative morbidity and long-term mortality [4]. The transapical approach (TA-TAVI) is considered a more invasive and complex procedure requiring general anesthesia, but provides superior control of valve positioning due to shorter distance, potential reduction of stroke due to absence of retrograde crossing of the aortic valve, and fewer access site complications [5]. The aim of this study was to evaluate the short-term and mid-term outcomes of patients undergoing TA-TAVI as a single-strategy option by a single-center multidisciplinary heart team.

\section{Material and methods}

All patients with severe symptomatic aortic stenosis and excessive risk related to open surgery were discussed by an institutional multidisciplinary heart team. Patients were considered as suitable candidates for transcatheter aortic valve implantation for technical surgical reasons (e.g., previous cardiac surgery, calcified ascending aorta not accessible for surgery) or because of a very high risk for a conventional operation (all reasons preventing the insertion of a catheter for external blood circulation, all conditions preventing from aortic clamping, reasons preventing surgical access of the mediastinum - the internal mammary artery or another critical conduit crossing the midline and/or adherent to the posterior table of the sternum, past history of mediastinal irradiation, burns, active mediastinitis). The absolute contraindications for TAVI were active or recent endocarditis or an annulus size that exceeded the recommendations of the valve manufacturers.

From June 2009 to December 2014, 41 patients with severe symptomatic aortic stenosis and excessive risk related to surgery were considered as suitable candidates for transcatheter aortic valve implantation, and all of them underwent transapical TAVI at our institution. All patients signed an informed consent form. The evaluation of early operative results was performed according to the Valve Academic Research Consortium (VARC)-2 consensus criteria [6]. These include device success endpoints and safety endpoints (all-cause mortality, major stroke, peri-procedural myocardial infarction, life-threatening bleeding, major vascular complications, and acute kidney injury), valve performance, and complications during hospitalization and at 30 days. Clinical efficacy was recorded after 30 days.

The impact of the learning curve on patient outcomes was analyzed by comparing the overall survival of the first
$30 \%$ of patients operated on during 2009-2012 versus the next $70 \%$ of patients operated on during 2013-2014. Also we evaluated the impact of previous cardiac operations and EuroSCORE I on patients undergoing TA-TAVI.

In all patients, multimodality imaging (transesophageal echocardiography, coronary angiography and multislice computed tomography) was performed to assess anatomic suitability, diameters of the aortic annulus, distribution and amount of calcification and aortic root geometry. Preoperative risk factors were defined according to the EuroSCORE I classification.

All TA-TAVI procedures were performed in a cath lab suitable for the use of a cardiopulmonary bypass machine by a multidisciplinary team of dedicated cardiac surgeons, interventional cardiologists and cardiac anesthesiologists. The procedures were performed under general anesthesia, and the only implanted devices were the SAPIEN pericardial transcatheter balloon expandable bioprosthesis (Edwards Lifesciences, Irvine, CA, USA). In all cases the balloon valvuloplasty was performed prior to valve deployment. All patients had transvenous temporary cardiac pacing during the procedure. Rapid ventricular pacing at 150-180 beats/min was performed to reduce cardiac motion, blood pressure and transvalvular flow during balloon dilatation. Positioning and deployment of the valve was performed under fluoroscopic and transesophageal guidance. Immediately after valve deployment, transesophageal echocardiography was used to confirm a good position and identify paravalvular leakage.

Patients underwent clinical and echocardiographic evaluation at our institute before the procedure, at discharge, at 1, 6 and 12 months after TAVI, and on a yearly basis thereafter.

\section{Statistical analysis}

Continuous variables were expressed as means (M) with standard deviation (SD) or medians (MD) with interquartile range $(\mathrm{IQR})$ and minimum-maximum range. Normality of the distributions was assessed using the D'Agostino-Pearson omnibus $K 2$ tests and with the Shapiro-Wilk normality test.

Non-parametric Mann-Whitney test was used to compare and study the relationships between the continuous variables.

Categorical variables were described as numbers and percentages (\%) and analyzed using the $\chi^{2}$ test or Fisher's exact test, as appropriate. A confidence level of $95 \%$ was accepted as significant.

Survival curves for time-to-event variables were constructed on the basis of all available follow-up data using Kaplan-Meier estimates and were compared with the log rank test. A two-sided $\alpha$ level of 0.05 was used for all superiority testing. A $p$-value $<0.05$ was considered to be significant.

The statistical analysis was performed with MS Excel 2003 for Windows XP and the statistical analysis system GraphPad Prism version 5.01 (Graph-Pad Software, Inc., San Diego, California, USA). 


\section{Results}

Between June 2009 and December 2014, 41 patients with severe symptomatic aortic stenosis with excessive risk related to surgery underwent TA-TAVI at our institution.

Preoperative clinical variables of patients are listed in Table I. Mean age was $79.6 \pm 6.3$ years, and mean logistic EuroSCORE I was $20.1 \pm 12.8 \%$. Eight patients (19.6\%) had a logistic EuroSCORE more than 30\%. There were 21 (51.2\%) male patients. Almost $9.8 \%$ of patients had severe peripheral vascular disease. There were 15 patients (36.5\%) who had already undergone cardiac surgery. The previous cardiac operation was CABG in 12 patients (29.3\%), mitral valve replacement with bioprosthesis in 2 patients (4.8\%) and a combined procedure (CABG + mitral valve replacement) in 1 patient (2.4\%). In 17 patients (41.5\%) with concomitant coronary artery disease, elective coronary artery stent implantation was performed, but not as a part of the TAVI procedure. Incidence of chronic renal insufficiency was $36.5 \%$ (15 patients) preoperatively; 1 patient was on chronic renal replacement therapy.

The procedure was performed using Edwards SAPIEN valves. A $23 \mathrm{~mm}$ SAPIEN valve was implanted in 9 patients (21.9\%), a $26 \mathrm{~mm}$ prosthesis in 20 patients (48.8\%) and a $29 \mathrm{~mm}$ prosthesis in 13 patients (31.7\%).

The operative results are displayed in Table II. The postoperative peak gradient over the prosthesis valve was $15.1 \mathrm{mmHg}$ and the mean gradient was $7.7 \mathrm{mmHg}$ as measured by transesophageal echocardiography. Mild-to-moderate post-implant paravalvular regurgitation was found in 8 (19.5\%) patients. In 2 patients, post-dilatation of the valve was performed with reduction of the leakage to a mild de-

Tab. II. Clinical operative results

\begin{tabular}{lc} 
Variables & TA-TAVI; $n=41(\%)$ \\
\hline \begin{tabular}{l} 
Valve size $(\mathrm{mm})$ \\
\hline 23
\end{tabular} & $9(21.9)$ \\
\hline 29 & $20(48.8)$ \\
\hline Peak gradient post-implant (mmHg) & $13(31.7)$ \\
\hline Mean gradient post-implant (mmHg) & $15.1 \pm 8.6$ \\
\hline Mild to moderate paravalvular leakage & $7.7 \pm 4.5$ \\
\hline Valve malpositioning & $8(19.5)$ \\
\hline $\begin{array}{l}\text { Second valve implanted (valve-in- } \\
\text {-valve) }\end{array}$ & $1(2.4)$ \\
\hline Intraoperative mortality & $1(2.4)$ \\
\hline Conversion to sternotomy & $1(2.4)$ \\
\hline Re-exploration (bleeding, tamponade) & $4(9.7)$ \\
\hline Intensive care unit stay (days) & $4.6 \pm 5.7$ \\
\hline Hospital stay (days) & $11.6 \pm 7.2$ \\
\hline TA-TAVI - transapical transcatheter aortic valve implantation
\end{tabular}

TA-TAVI - transapical transcatheter aortic valve implantation gree. In this group of 8 patients, there were 5 patients with the position of the prosthesis deeper into the left ventricle outflow tract. Conversion to sternotomy was required in 1 patient because of annular rupture.

Clinical endpoints according to VARC-2 definitions are reported in Table III. Intraprocedural mortality occurred in 1 patient (2.4\%). The need for re-exploration for bleeding

Tab. I. Preoperative characteristics

\begin{tabular}{lc} 
Variables & TA-TAVI; $n=41(\%)$ \\
Male gender & $21(51.2)$ \\
\hline Age (years) & $79.7 \pm 6.6$ \\
\hline EuroSCORE & $20.1 \pm 12.78$ \\
\hline Hypertension & $39(95.1)$ \\
\hline Diabetes mellitus & $15(36.5)$ \\
\hline CAD & $25(61)$ \\
\hline COPD & $13(31.7)$ \\
\hline Peripheral vascular disease & $4(9.8)$ \\
\hline History of stroke/TIA & $6(14.6)$ \\
\hline Preoperative pacemaker & 0 \\
\hline Chronic kidney insufficiency & $15(36.5)$ \\
\hline Chronic hemodialysis & $1(2.4)$ \\
\hline LV function more than $50 \%$ & $24(58.6)$ \\
\hline LV function between 30 and $50 \%$ & $14(34.1)$ \\
\hline LV function less than $30 \%$ & $3(7.3)$ \\
\hline Previous heart surgery & $15(36.5)$ \\
\hline Annular diameter (mm) & $23.8 \pm 1.8$ \\
\hline Transaortic peak gradient $(\mathrm{mmHg})$ & $72.6 \pm 20.1$ \\
\hline Transaortic mean gradient $(\mathrm{mmHg})$ & $44.1 \pm 12.7$ \\
\hline Indexed aortic valve orifice $\left(\mathrm{cm} 2 / \mathrm{m}^{2}\right)$ & $0.38 \pm 0.12$ \\
\hline
\end{tabular}

$\mathrm{LV}$ - left ventricle, CAD - coronary artery disease, COPD - chronic obstructive pulmonary disease, TIA - transient ischemic attack, TA-TAVI - transapical transcatheter aortic valve implantation

Tab. III. Clinical endpoints according to VARC-2 criteria $(n=41)$

\begin{tabular}{lc} 
Variables & TA-TAVI; $n=41(\%)$ \\
Immediate procedural mortality $(<72 \mathrm{~h})$ & $1(2.4)$ \\
\hline Periprocedural myocardial infarction $(\%)$ & 0 \\
\hline Stroke (CVA/TIA) & $1(2.4)$ \\
\hline Life-threatening or disabling bleeding & $4(9.7)$ \\
\hline Acute kidney injury & $4(9.7)$ \\
\hline Coronary obstruction requiring interven- & 0 \\
\hline tion & 0 \\
\hline Major access-related complications & $3(7.3)$ \\
\hline Permanent pacemaker implantation &
\end{tabular}


or tamponade arose in 4 patients (9.7\%). One patient experienced a major stroke (2.4\%), and 4 patients (9.7\%) had acute kidney injury requiring renal replacement therapy. We did not observe any apex-access complications. No patients experienced acute myocardial infarction or coronary obstruction that required percutaneous angioplasty.

Device success as defined by VARC- 2 was achieved in $75.6 \%$ of cases (Table IV). Device success criteria were not met in 10 patients for the following reasons: procedural mortality in 1 patient (2.4\%), suboptimal performance of the prosthetic heart valve, mild-to-moderate prosthetic paravalvular regurgitation in 8 patients (19.5\%), and 1 (2.4\%) rescue "valve-in-valve" implantation due to prosthesis migration to the left ventricle immediately after implantation [7].

Early safety at 30 days as defined by VARC-2 was achieved in 24 patients (58.8\%) (Table V). All-cause mortality at 30 days or during procedure hospitalization was $17.1 \%$ (7 patients), and was classified as cardiovascular mortality. Intraprocedural mortality occurred in 1 patient

Tab. IV. Composite endpoints, device success according to VARC-2 criteria $(n=41)$

\begin{tabular}{lcc} 
& $n$ & $\%$ \\
Device success & 31 & 75.6 \\
\hline Absence of procedural mortality & 40 & 97.56 \\
\hline Correct positioning of a single prosthetic heart valve & 40 & 97.56 \\
\hline Intended performance of the prosthetic heart valve & 33 & 80.5 \\
\hline
\end{tabular}

Tab. V. Composite endpoints, early safety (at 30 days) according to VARC- 2 criteria $(n=41)$

\begin{tabular}{lcc} 
& $n$ & $\%$ \\
\hline Early safety & 24 & 58.5 \\
\hline Absence of all-cause mortality & 34 & 82.9 \\
\hline Absence of all stroke & 40 & 97.56 \\
\hline Absence of life-threatening bleeding & 37 & 90.2 \\
\hline Absence of AKI & 37 & 90.2 \\
\hline Absence of coronary obstruction & 41 & 100 \\
\hline Absence of major vascular complications & 41 & 100 \\
\hline $\begin{array}{l}\text { Absence of valve-related dysfunction requiring } \\
\text { repeat procedure }\end{array}$ & 40 & 97.56 \\
\hline AKI - acute kidney injury & &
\end{tabular}

Tab. VI. Composite endpoints, clinical efficacy (after 30 days) according to VARC-2 criteria $(n=34)$

\begin{tabular}{lcc} 
Clinical efficacy & $n$ & $\%$ \\
\hline All-cause mortality & 21 & 61.7 \\
\hline All stroke & 6 & 17.6 \\
\hline Requiring hospitalization & 0 & \\
\hline Valve-related dysfunction & 2 & 5.9 \\
\hline
\end{tabular}

(2.4\%), death of multiorgan failure in 4 patients $(9.7 \%)$, severe hemorrhage in 1 patient (2.4\%), and 1 patient died in a local hospital (2.4\%). In 4 patients (9.7\%) reexploration for bleeding was necessary. After full sternotomy in 2 patients and thoracotomy in 2 patients, we found diffuse bleeding in 3 patients. In the last patient we found a hematoma around the aortic root and massive untreatable bleeding from the free wall of the left ventricle and base of the heart. In 1 patient (2.4\%), conversion to sternotomy and surgical aortic valve replacement after deployment of the balloon-expandable prosthesis was necessary due to annular rupture. One patient experienced a major stroke $(2.4 \%)$ and 4 patients $(9.7 \%)$ had acute kidney injury requiring renal replacement therapy. We did not observe any apex-access complications.

Clinical efficacy after 30 days according to VARC-2 clinical guidelines is reported in Table VI and was reached in $61.7 \%$ of patients. There were another 6 deaths during the follow-up. No other patients experienced a stroke. Incidence of permanent pacemaker implantation for complete atrioventricular conduction block was 7.3\% (3 patients). Two patients required hospitalization for worsening of congestive heart failure and thoracotomy wound healing complication during the follow-up. In 5 patients moderate paravalvular leakage without significant clinical symptoms persists.

VARC-2 included a new composite endpoint, time-related valve safety, which combines valve dysfunction, endocarditis, and thrombotic complications of the prosthesis. The specific composite endpoint time-related valve safety was achieved in $79.4 \%$ of surviving patients during the follow-up. In our group of patients we observed 1 infective endocarditis of the prosthesis, and 1 patient underwent surgical valve replacement 6 months after TAVI. During the redo operation we did not find structural deterioration of the prosthetic valve, but 1 calcified leaflet of the native valve caused the obstruction of the normal leaflet motion of the transcatheter valve prosthesis.

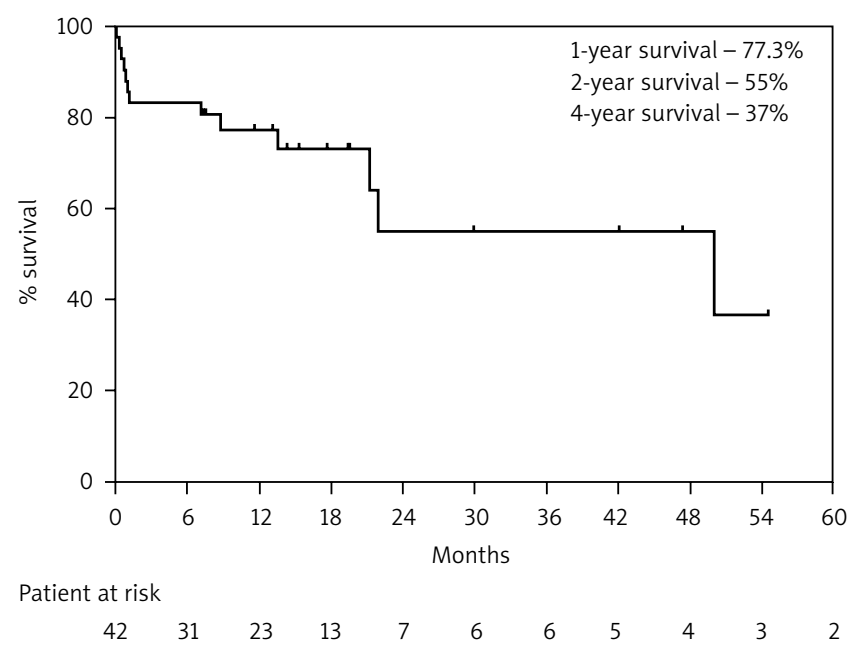

Fig. 1. Kaplan Meier analysis of overall survival of all patients underwent TA-TAVI 
Median stay in the intensive care unit was 1 day (interquartile range IQR, 1-6.5 days, range 0-24 days), and median hospital stay was 9 days (IQR, 8-14.5 days, range 1-39 days).

\section{Follow-up}

The median follow-up was 12.7 months (IQR, 4.1-20.75 months, range 0.1-55.6 months).

Overall Kaplan-Meier 1-year survival was $77.3 \% \pm 6.8 \%$, 2 -year survival was $55 \% \pm 12.5 \%$, and 4 -year survival was $37 \% \pm 17 \%$ (Fig. 1).

We did not observe any statistical significant differences in 1-year survival at follow-up related to reoperation.

A

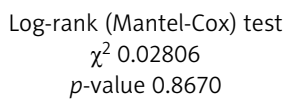

NS

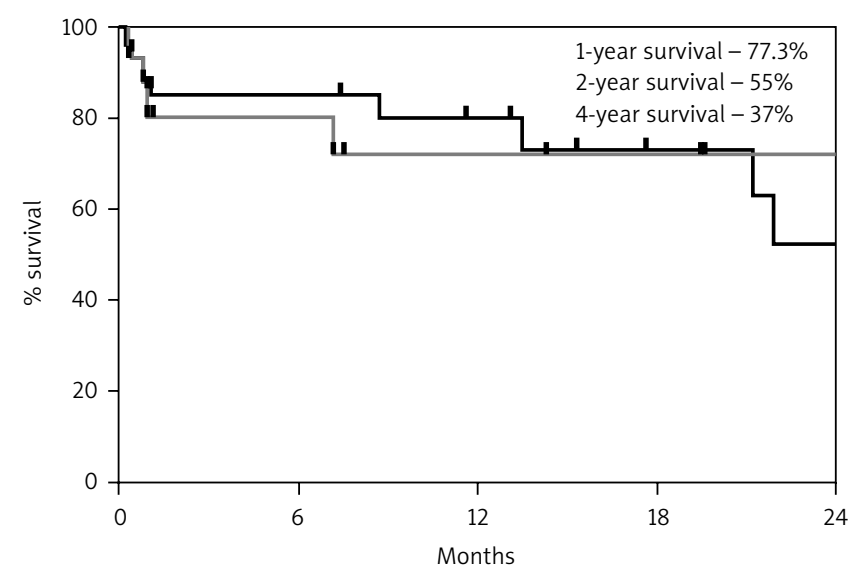

Patient at risk

PRIMO 27

REDO 15

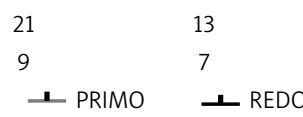

Log-rank (Mantel-Cox) test

$\chi^{2} 0.5152$

$p$-value 0.4729

NS

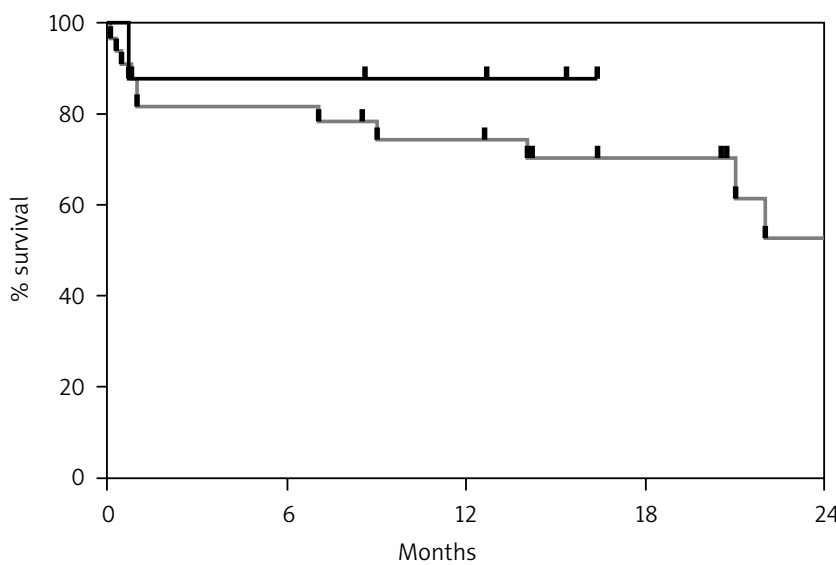

Patient at risk

EuroSCORE 33

$\leq 30 \%$

EurOSCORE 8

$>30 \%$

$\begin{array}{ccc}24 & 19 & 16 \\ 7 & 4 & 1 \\ \mathbf{2} 2009-2012 & \perp 2013-2014\end{array}$

Kaplan-Meier survival was similar for the patients who underwent TA-TAVI as a first procedure $(80.2 \% \pm 8.1 \%)$ and patients who underwent TA-TAVI as a second operation $(72 \%$ $\pm 12 \%, p=0.87$ ) (Fig. 2A).

Kaplan-Meier analysis of 1-year survival related to the learning curve was $62 \% \pm 13.5 \%$ for the first $30 \%$ of patients and $82 \% \pm 7.3 \%$ for the second $70 \%$ of patients ( $p=0.21$, statistically not significant).

Up to 14 months the differences between curves increased, but they were still not statistically significant in this small group of patients. There was a trend to worse survival at the beginning of the learning curve (Fig. 2B).

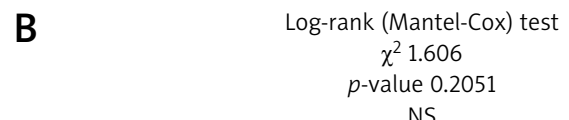

NS

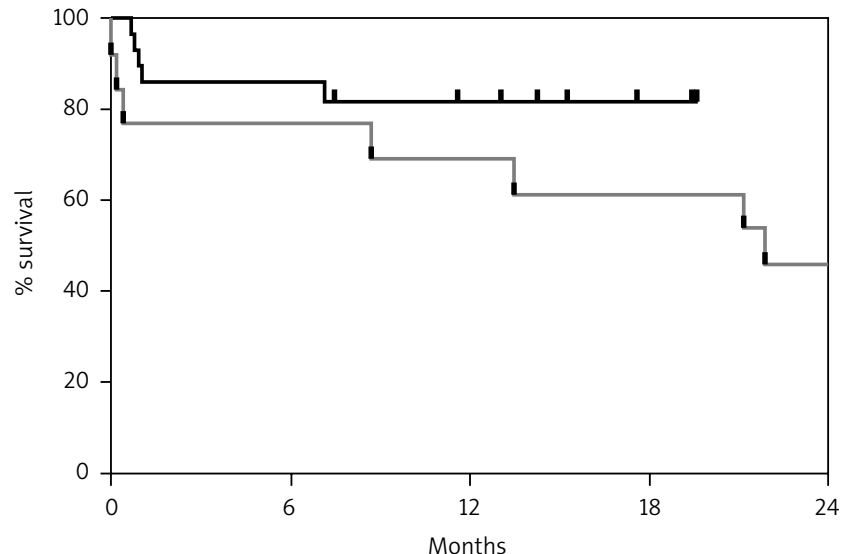

Patient at risk

2009- 13

2012

2013- 28

11

21

9

8

7

2014

+2009-2012 2013-2014

Fig. 2. A) All-cause Kaplan-Meier survival of group PRIMO (first operation) (black line) and group REDO (reoperation) (grey line). B) Kaplan-Meier analysis of overall mortality of patients operated between years 2009-2012 (30\%) (grey line), and the patients ope-

7 rated between years 2013-2014 (70\%) (black line). C) Kaplan-Meier survival for patients with different risk profile according to classification of EuroSCORE I: EuroSCORE $\leq 30 \%$ (grey line), EuroSCORE $>30$ (black line) 
Based on EuroSCORE I, in the group with the EuroSCORE $\leq 30 \%$, the survival rate at 1 year was $74.5 \% \pm 9.9 \%$, and in the group with the EurOSCORE > 30\%, the 1-year survival rate was $87.5 \% \pm 11.7 \%$ (statistically insignificant, $p=0.52$ ) (Fig. 2C).

There was no case of structural valve deterioration during the follow-up. We observed 1 case of infective endocarditis.

\section{Discussion}

The prognosis in symptomatic patients with severe aortic valve stenosis is poor if treated medically [8]. After symptoms onset, the 1-year mortality rate is reported around $30 \%$. Conventional open surgical treatment of severe aortic valve stenosis in high-risk patients can be effectively performed with excellent outcomes and an observed hospital mortality rate ranging from 0 to $8 \%$ and a 1-year survival rate of around $90 \%$ of patients in the majority of recently published series $[9,10]$. However, the risk of surgical mortality increases significantly with age [11]. Surgeons sometimes hesitate to perform surgical valve replacement in this group of elderly patients, or patients themselves or their practitioners are reluctant to undergo surgical intervention.

Transcatheter aortic valve implantation (TAVI) has been developed as a minimally invasive alternative to open surgery, especially in patients with unacceptably high perioperative risk or patients who are not suitable for conventional surgery. TAVI became a very attractive, safe and effective therapeutic option which can be performed with acceptable mortality rate [12]. The salient findings from 2-year analysis of the randomized PARTNER trial are as follows: mortality after transcatheter aortic valve replacement (TAVR) remained similar to that after surgical replacement; stroke frequency was similar in the surgery and TAVR groups after 30 days; periprocedural complications (strokes, major bleeding, and major vascular events) affected mortality after TAVI or surgical replacement; aortic regurgitation (even mild) after TAVI was associated with increased long-term mortality; and valve performance in the TAVI group was maintained during the follow-up and was similar to that in the surgery group [12].

In the literature there is limited available information which directly compares transfemoral transcatheter aortic valve implantation (TF-TAVI) and transapical aortic valve implantation (TA-TAVI) [13].

Van der Boon and colleagues reported the results of a multicenter collaborative study. In that study a total of 882 patients underwent TAVI, of whom only 10.1\% (89 patients) underwent TA-TAVI.

The authors found that in institutions with predominant TF-TAVI practice, TA-TAVI is associated with an increased risk of 30-day mortality and all-cause mortality during the follow-up. Moreover, patients undergoing TA-TAVI had a longer hospital stay but fewer vascular complications in comparison with TF-TAVI [13]. The transfemoral approach is preferably the first choice access because it can be carried out completely percutaneously and without any general anesthesia. Transapical patients usually have a higher esti- mated preoperative risk prediction and higher incidence of comorbidities [14].

Our reasons for the strategy of a "clear transapical approach" for all high-risk patients considered as candidates for TAVI are more precise control and deployment of the valve in the correct position, and better and more intuitive manipulation with the device at a shorter distance. In the last patients we decided to perform angiography during the valve deployment while inflating the balloon, as described by Pasic et al. as part of "the Berlin addition" [15]. Angiography enabled perfect visualization of the position of the prosthetic valve and its relationship to the coronary arteries, aortic valve annulus and valve cusps throughout the valve deployment. Angiography during deployment of the valve presents the coronary arteries immediately at the end of the valve deployment. Angiographic visualization improves the safety of transapical aortic valve implantation and simplifies valve positioning and the valve-deploying technique [15].

The inflation of the balloon during valve deployment can be performed slowly, allowing easy correction of the position of the valve if necessary. Advancing the wire in an antegrade direction through the valve is very easy, rapid, and smooth in comparison to the retrograde approach used with transfemoral implantation. Also the transapical approach is independent of the degree of the patient's peripheral artery disease, calcification, diameter and other anatomical variables of the inguinal and iliac vessels.

The reported rates of moderate or severe regurgitation during the TAVI procedure vary between $10 \%$ and up to $20 \%$ or more in larger series, regardless of the type of prosthesis [16]. Paravalvular regurgitation (PVR) of some degree is observed and accepted in the majority of transcatheter aortic valve implantation patients. Regurgitation after TAVI is known to have a negative impact on mid-term and longterm survival [12]. Unbehaun and colleagues reported mild to moderate regurgitation in $20 \%$ of patients $[17,18]$. Results from the Italian Registry of TA-TAVI showed that $45 \%$ of patients had mild or moderate aortic regurgitation at hospital discharge [19]. O'Sullivan et al. summarized in their work that there are two anatomical, non-modifiable factors which have an impact on the likelihood of PVR: aortic valve calcification and LVOT-AO angle. There are two other valverelated, modifiable factors that determine the incidence of PVR: prosthesis-annulus discongruence and valve position [20]. In our series we observed mild-to-moderate regurgitation in $19.5 \%$ of patients.

We observed only 1 post-procedural stroke (2.4\%) and no other stroke during the follow-up. Our result is comparable to a recent meta-analysis of 10037 patients from 53 studies showing the incidence rate of major stroke at 30 days being $2.9 \pm 1.8 \%$ [21]. The absence of retrograde crossing of the aortic valve and lack of manipulation in the aortic arch may reduce or eliminate cerebral embolization during this phase of the procedure and decreased the rate of neurological complications. Our reported incidence of perioperative stroke is very encouraging. 
We observed 1 conversion to sternotomy (2.4\%) due to annular rupture and surgical replacement of the transcatheter valve with a bioprosthesis, as well as 4 re-explorations (9.7\%) because of bleeding or tamponade. The incidence of permanent pacemaker implantation due to complete atrioventricular conduction block was 7.3\%. We did not observe any apex access complication or periprocedural coronary obstruction requiring intervention.

Our observed 30 -day mortality rate was $17.1 \%$, reflecting the high-risk profile of these patients and the early experience and learning curve with these methods. At the beginning of the TAVI program in our institution, when all high-risk patients were considered as candidates for TAVI regardless of comorbidities and clinical status, we did not follow the "No exclusion" policy as reported by Pasic and his Berlin colleagues [22]. We tried to select the most highrisk, extremely fragile patients and did not schedule them for the TAVI procedure. D'Onofrio and colleagues reported a 30-day mortality of $9.9 \%$ in 774 patients undergoing TA-TAVI [19]. Van der Boone et al. observed $15.7 \%$ in-hospital mortality among 89 patients undergoing TA-TAVI [13].

The 1 -year survival rate in our group was $77.3 \%$. Johansson et al. [14] reported a late survival after TAVI of $77 \%$ both at 6 months and 1 year. D'Onofrio et al. [19] reported overall 1 -year survival of $81.7 \%$, and Van der Boon et al. [13] reported 1-year survival of $68 \%$ of TA-TAVI patients.

The 4-year survival rate was $37 \%$ in our study group.

Rodés-Cabau et al. published the results of 339 patients, including 177 patients after TA-TAVI with a 4-year survival rate of $43 \%$, and summarized that TAVI in patients considered to be inoperable or at very high surgical risk was associated with good hemodynamic results translating into a significant functional improvement in most patients. The mortality rate at a mean follow-up of 3.5 years after the procedure remained relatively high (>50\%) [23]. Patients with COPD, chronic kidney disease, frailty, and chronic atrial fibrillation were at higher risk of death within the few years after TAVI, suggesting that a more careful evaluation and follow-up of patients with these comorbidities might translate into better mid- to long-term outcomes [23]. Toggweiler et al. [24] published a single-center experience of 5 -year outcomes in 24 transapical TAVI patients with a survival rate of $35 \%$.

The early mortality is increased if an intraprocedural complication such as resuscitation, conversion to conventional surgery or reexploration because of bleeding occurs.

The experience of Pasic et al. [22] with the TAVI program confirmed that a small, but certain, number of patients would have a possibly detrimental intraprocedural complication (e.g., annular rupture) that is difficult to manage. This is the main disadvantage of TAVI compared with conventional aortic valve surgery. Therefore, the main problem of TAVI remains the uncertainty about the definitive result at the end of the procedure [22].

Unbehaun et al. found, most interestingly, that age itself was not predictive of survival in their patients. It con- firms that comorbidities rather than advanced age itself determine midterm survival. They observed that later survival is negatively influenced by various noncardiac comorbidities, such as reduced pulmonary function, chronic renal failure, or advanced stages of peripheral arterial diseases. The combination of several comorbidities, as reflected by higher values of the applied risk scores (the logistic EurOSCORE and the STS score), was not different between 30-day survivors and nonsurvivors but was found to be a very sensitive predictor for survival during follow-up [25].

\section{Limitations}

The study is limited by the small number of patients and the lack of a control group.

\section{Conclusions}

Transapical transcatheter aortic valve implantation should be considered as a feasible therapeutic option in a selected patient population. The transapical approach is a complex procedure that requires training, and the learning curve may affect the outcomes. The learning curve is crucial not only for the technique of implantation but also for patient selection, valve sizing, positioning and postdilatation, which can affect early mortality and morbidity of the patients. With increasing experience, the rate of complications and the mortality rate are believed to decline. The transapical approach is not associated with a higher incidence of apex-related complications. Transcatheter aortic valve implantation can be performed with an acceptable early and mid-term survival rate.

Very low rates of strokes (2.4\%) and vascular complications (\%) in our patients are further benefits of the short and antegrade approach.

\section{Disclosure}

Authors report no conflict of interest.

\section{References}

1. Vahanian A, Baumgartner H, Bax J, Butchart E, Dion R, Filippatos G, Flachskampf F, Hall R, lung B, Kasprzak J, Nataf P, Tornos P,Torracca L, Wenink A; Task Force on the Management of Valvular Hearth Disease of the European Society of Cardiology; ESC Committee for Practice Guidelines. Guidelines on the management of valvular heart disease: The Task Force on theManagement of Valvular Heart Disease of the European Society of Cardiology. Eur Heart J 2007; 28: 230-268.

2. Charlson E, Legedza AT, Hamel MB. Decision-making and outcomes in severe symptomatic aortic stenosis. J Heart Valve Dis 2006; 15: 312-321.

3. Kappetein AP, Head SJ, Treede H, Reichenspurner H, Mohr FW, Walther T. What is the evidence allowing us to state that transcatheter aortic valve replacement viathe femoral artery is a more attractive option compared to transapical valve replacement? Eurolntervention 2011; 7: 903-904.

4. Généreux P, Webb JG, Svensson LG, Kodali SK, Satler LF, Fearon WF, Davidson CJ, Eisenhauer AC, Makkar RR, Bergman GW, Babaliaros V, Bavaria JE, Velazquez OC, Williams MR, Hueter I, Xu K, Leon MB; PARTNER Trial Investigators. Vascular complications after transcatheter aortic valve replacement: insights from thePARTNER (Placement of AoRTic TraNscathetER Valve) trial. J Am Coll Cardiol 2012; 60: 1043-1052.

5. Walther T, Dewey T, Borger MA, Kempfert J, Linke A, Becht R, Falk V, Schuler G, Mohr FW, Mack M. Transapical aortic valve implantation: step by step. Ann Thorac Surg 2009; 87: 276-283. 
6. Kappetein AP, Head SJ, Généreux P, Piazza N, van Mieghem NM, Blackstone EH, Brott TG, Cohen DJ, Cutlip DE, van Es GA, Hahn RT, Kirtane AJ, Krucoff MW, Kodali S, Mack MJ, Mehran R, Rodés-Cabau J, Vranckx P, Webb JG, Windecker S, Serruys PW, Leon MB; Valve Academic ResearchConsortium-2. Updated standardized endpoint definitions for transcatheter aortic valve implantation: the Valve Academic Research Consortium-2 consensusdocument. J Thorac Cardiovasc Surg 2013; 145: 6-23.

7. Čanádyová J, Mokráček A, Pešl L, Kurfirst V. How to manage left ventricular embolization of the transcatheter valve. Kardiochir Torakochir Pol 2015; 12: 53-55.

8. Varadarajan P, Kapoor N, Bansal RC, Pai RG. Clinical profile and natural history of 453 nonsurgically managed patients with severeaortic stenosis. Ann Thorac Surg 2006; 82: 2111-2115.

9. Thourani VH, Ailawadi G, Szeto WY, Dewey TM, Guyton RA, Mack MJ, Kron IL, Kilgo P, Bavaria JE. Outcomes of surgical aortic valve replacement in high-risk patients: a multiinstitutional study. Ann Thorac Surg 2011; 91: 49-55.

10. Grossi EA, Schwartz CF, Yu PJ, Jorde UP, Crooke GA, Grau JB, Ribakove GH, Baumann FG, Ursumanno P, Culliford AT, Colvin SB, Galloway AC. High-risk aortic valve replacement: are the outcomes as bad as predicted? Ann Thorac Surg 2008; 85: 102-106.

11. Bose AK, Aitchison JD, Dark JH. Aortic valve replacement in octogenarians. J Cardiothorac Surg 2007; 2: 33.

12. Kodali SK, Williams MR, Smith CR, Svensson LG, Webb JG, Makkar RR, Fontana GP, Dewey TM, Thourani VH, Pichard AD, Fischbein M, Szeto WY, Lim S, Greason KL, Teirstein PS, Malaisrie SC, Douglas PS, Hahn RT, Whisenant B, Zajarias A, Wang D,Akin JJ, Anderson WN, Leon MB; PARTNER Trial Investigators. Two-year outcomes after transcatheter or surgical aortic-valve replacement. N Engl J Med 2012; 366: 1686-1695.

13. van der Boon RM, Marcheix B, Tchetche D, Chieffo A, Van Mieghem NM, Dumonteil N, Vahdat O, Maisano F, Serruys PW,Kappetein AP, Fajadet J, Colombo A, Carrié D, van Domburg RT, de Jaegere PP. Transapical versus transfemoral aortic valve implantation: a multicenter collaborativestudy. Ann Thorac Surg 2014; 97: 22-28.

14. Johansson M, Nozohoor S, Kimblad PO, Harnek J, Olivecrona GK, Sjögren J. Transapical versus transfemoral aortic valve implantation: a comparison of survival andsafety. Ann Thorac Surg 2011; 91: 57-63.

15. Pasic M, Dreysse S, Drews T, Buz S, Unbehaun A, Kukucka M, Mladenow A, Hetzer R. Improved technique of transapical aortic valve implantation: "the Berlin addition". Ann Thorac Surg 2010; 89: 2058-2060.

16. Tamburino C, Capodanno D, Ramondo A, Petronio AS, Ettori F, Santoro G, Klugmann S, Bedogni F, Maisano F, Marzocchi A, Poli A, Antoniucci D, Napo- dano M, De Carlo M, Fiorina C, Ussia GP. Incidence and predictors of early and late mortality after transcatheter aortic valve implantation in 663 patients with severe aortic stenosis. Circulation 2011; 123: 299-308.

17. Unbehaun A, Pasic M, Drews T, Penkalla A, Dreysse S, Klein C, Kukucka M, Mladenow A, Hetzer R, Buz S.Transapical aortic valve implantation: predictors of survival up to 5 years in 730 patients. An update. Eur J Cardiothorac Surg 2015; 47: 281-290.

18. Unbehaun A, Pasic M, Dreysse S, Drews T, Kukucka M, Mladenow A, Ivanitskaja-Kühn E, Hetzer R, Buz S. Transapical aortic valve implantation: incidence and predictors of paravalvular leakageand transvalvular regurgitation in a series of 358 patients. J Am Coll Cardiol 2012; 59: 211-221.

19. D’Onofrio A, Salizzoni S, Agrifoglio M, Cota L, Luzi G, Tartara PM, Cresce GD, Aiello M, Savini C, Cassese M, Cerillo A, Punta G,Cioni M, Gabbieri D, Zanchettin C, Agostinelli A, Mazzaro E, Di Gregorio O, Gatti G, Faggian G, Filippini C, Rinaldi M, Gerosa G. Medium term outcomes of transapical aortic valve implantation: results from the ItalianRegistry of Trans-Apical Aortic Valve Implantation. Ann Thorac Surg 2013; 96: 830-835.

20. O'Sullivan KE, Gough A, Segurado R, Barry M, Sugrue D, Hurley J. Is valve choice a significant determinant of paravalular leak post-transcatheter aortic valveimplantation? A systematic review and meta-analysis. Eur J Cardiothorac Surg 2014; 45: 826-833.

21. Eggebrecht $H$, Schmermund A, Voigtländer T, Kahlert P, Erbel R, Mehta RH. Risk of stroke after transcatheter aortic valve implantation (TAVI): a meta-analysis of10,037 published patients. Eurolntervention 2012; 8: 129-138.

22. Pasic M, Unbehaun A, Dreysse S, Buz S, Drews T, Kukucka M, Mladenow A, D’Ancona G, Hetzer R, Seifert B. Introducing transapical aortic valve implantation (part 1): effect of a structured trainingprogram on clinical outcome in a series of 500 procedures. J Thorac Cardiovasc Surg 2013; 145: 911-918.

23. Rodés-Cabau J, Webb JG, Cheung A, Ye J, Dumont E, Feindel CM, Osten M, Natarajan MK, Velianou JL, Martucci G, DeVarennes B, Chisholm R, Peterson MD, Lichtenstein SV, Nietlispach F, Doyle D, DeLarochellière R, Teoh K, Chu V, Dancea A, Lachapelle K, Cheema A, Latter D, Horlick E. Transcatheter aortic valve implantation for the treatment of severe symptomatic aortic stenosis in patients at very high or prohibitive surgical risk: acute and late outcomes of the multicenter Canadian experience. J Am Coll Cardiol 2010; 55: 1080-1090.

24. Toggweiler S, Humphries KH, Lee M, Binder RK, Moss RR, Freeman M, Ye J, Cheung A, Wood DA, Webb JG. 5-year outcome after transcatheter aortic valve implantation. J Am Coll Cardiol 2013; 61: 413-419.

25. Unbehaun A, Pasic M, Drews T, Dreysse S, Kukucka M, Hetzer R, Buz S. Analysis of survival in 300 high-risk patients up to 2.5 years after transapical aortic valve implantation. Ann Thorac Surg 2011; 92: 1315-1323. 